\title{
Model Pembelajaran ECIRR (Elicit-Confront- Identify-Resolve-Reinforce) Untuk Meningkatkan Hasil Belajar Pada Materi Gerak Lurus
}

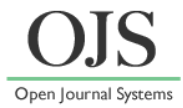

\author{
Askha Meliana Adi Ningrum*,Suliyanah \\ Jurusan Fisika, Fakultas Matematika dan Ilmu Pengetahuan Alam, Universitas Negeri Surabaya \\ *Email: askha.17030184073@mhs.unesa.ac.id \\ DOI: https://doi.org/10.33369/pendipa.5.3.444-450
}

\begin{abstract}
The aim of this study was to determine the increase in student learning outcomes before and after learning using the ECIRR model. The method used in this research is a pre-experimental method with one group pre-test post-test design. The population in this study was students of class X MIPA SMA Negeri 1 Ponggok which consisted of 5 classes. Sampling using simple random sampling technique which is done randomly then selected XA1, XA2, and XA3. Research instruments in the form of observation sheets as indicator of the implementation of the learning process and pre-test post-test questions as indicators of improving learning outcomes. An increase in learning outcomes can be seen from the increase in the pre-test and post-test scores. Based on the results of the research data analysis, it was concluded that the implementation of learning using the ECIRR model was categorized as moderate and could improve student learning outcomes in the moderate category.
\end{abstract}

Keywords: ECIRR learning model, Learning Outcomes, Straight Motion.

\begin{abstract}
ABSTRAK
Penelitian ini bertujuan untuk mengetahui peningkatan hasil belajar peserta didik sebelum dan sesudah pembelajaran menggunakan model ECIRR. Metode yang digunakan dalam penelitian adalah metode pre-experimental dengan one group pre-test post-test design. Populasi pada penelitian ini adalah peserta didik kelas X MIPA SMA Negeri 1 Ponggok yang terdiri dari 5 kelas. Pengambilan sampel menggunakan teknik simple random sampling yang dilakukan secara acak kemudian terpilih XA1, XA2, dan XA3. Instrumen penelitian berupa lembar pengamatan sebagai indikator keterlaksanaan proses pembelajaran dan soal pre-test post-test sebagai indikator peningkatan hasil belajar. Peningkatan hasil belajar dapat dilihat dari peningkatan nilai pre-test dan post-test. Berdasarkan hasil analisis data penelitian diperoleh kesimpulan bahwa keterlaksanaan pembelajaran menggunakan model ECIRR didapatkan berkategori sedang dan hasil belajar peserta didik meningkat dalam kategori sedang.
\end{abstract}

Kata kunci: Model pembelajaran ECIRR, Hasil belajar, Gerak Lurus.

\section{PENDAHULUAN}

Fisika merupakan cabang ilmu yang mempelajari fenomena alam mulai dari wujud zat serta energinya. Tujuan dari pembelajaran fisika adalah untuk menguasai konsep, pengetahuan dan prinsip fisika sebagai bekal melanjutkan pendidikan pada jenjang yang lebih tinggi dan juga dapat diterapkan dalam kehidupan sehari-hari. Pada pembelajaran di kelas peserta didik memperoleh pengetahuan berupa informasi yang telah disampaikan oleh guru. Namun cara berfikir setiap peserta didik tidak sama, ada yang memproses informasi tersebut dengan benar ada juga yang memproses 
informasi tersebut dengan salah atau kurang tepat.

Pada penelitian yang dilakukan oleh Mustofa dan Rusdiana dalam jurnal pada tahun 2016 dengan judul "Profil Kemampuan Pemecahan Masalah Siswa Pada Pembelajaran Gerak Lurus" menyimpulkan bahwa indikator mengevaluasi solusi dengan persentase sebesar 20\%. Peserta didik memiliki kemampuan memecahkan masalah dengan rata-rata $52,57 \%$. Peserta didik mengakui bahwa saat menjawab soal tes jawaban didapatkan peserta didik secara spontan dan berdasarkan pemikiran mereka sendiri sehingga dapat disimpulkan bahwa mereka hanya menebak jawaban. Hal tersebut biasa terjadi karena pada saat pembelajaran peserta didik hanya terfokus pada rumus tanpa menganalisis lebih jauh konsep dari materi gerak tersebut. Adanya ketidakseimbangan dalam diri peserta didik mempermudah terjadinya suatu perubahan konseptual dalam diri peserta didik. Salah satu model pembelajaran yang mampu menunjang pengetahuan awal dengan strategi konflik kognitif untuk perubahan konseptual adalah model pembelajaran ECIRR (Elicit-Confront-Identify-ResolveReinforce).

Wenning (2008) mengusulkan suatu pendekatan atau model baru untuk mengatasi konsepsi alternatif pada pembelajaran fisika yang disebut model pembelajaran ECIRR. Model tersebut dikembangkan dari model CCM dan CEM berdasarkan penelitian dari modeling website. Model pembelajaran ini merupakan suatu model baru dalam pembelajaran yang berfasilitas strategi perubahan konseptual untuk memperbaiki konsep alternatif yang dimiliki peserta didik menjadi konsep ilmiah (Jayanti, et.al, 2014).

Model pembelajaran ECIRR memiliki 5 tahap pembelajaran. Tahap pertama adalah tahap elicit, pada tahap ini guru memberikan aktivitas yang merangsang peserta didik untuk berpikir dan peserta didik menjawab pertanyaan konseptual yang diberikan guru untuk menggali pengetahuan awal. Selanjutnya adalah tahap confront, guru menunjukkan fenomena fisika untuk menyesuaikan konsepsi awal peserta didik. Kemudian peserta didik membandingkan konsep awal yang sudah di miliki dengan konsep pada fenomena yang diberikan. Tahap identify merupakan tahap yang sangat penting. Guru memberikan pengetahuan untuk menjelaskan konsepsi awal yang peserta didik alami. Kemudian peserta didik memberikan jawaban sangkalan atas keyakinan atau ketidakyakinan atas konsep awal yang peserta didik miliki. Selanjutnya pada tahap resolve, yaitu guru memberikan konsep yang benar dengan menunjukkan bukti dari fenomena yang teramati. Dalam hal ini dilakukan praktikum virtual menggunakan Phet Simulation Collorado dan peserta didik dapat mengubah konsep awal yang masih keliru dengan konsep baru yang telah di dapat. Pada tahap terakhir adalah reinforce, pada tahap ini guru memberikan penguatan dengan cara mereview dan memberikan pertanyaan tentang konsep yang benar kepada peserta didik. Dari uraian di atas maka dilakukan penelitian dengan menerapkan pembelajaran model ECIRR untuk meningkatkan hasil belajar peserta didik pada materi gerak lurus.

\section{METODE PENELITIAN}

Penelitian yang dilakukan merupakan penelitian eksperimen (experimental). Penelitian eksperimen bertujuan untuk mencari pengaruh dari suatu perlakuan dimana pada penelitian ini adalah perlakuan model pembelajaran ECIRR terhadap yang lain dengan kondisi yang dikendalikan. Eksperimen pada penelitian ini bertujuan untuk melihat akibat dari perlakuan tertentu. Metode yang digunakan dalam penelitian ini adalah metode Pre-Experimental dengan One Group Pre-test-Post-test Design dengan satu perlakuan. Pada peneltian ini didapatkan hasil data berupa data kuantitatif yang diperoleh dari hasil pretest dan posttest yang telah diujikan pada sampel. Populasi dalam penelitian ini adalah peserta 
didik kelas $\mathrm{X}$ MIPA SMA Negeri 1 Ponggok yang terdiri atas 5 kelas yaitu XA1, XA2, XA3, XA4 dan XA5. Pada penelitian ini menggunakan 3 sampel yaitu XA1, XA2, dan XA3. Pemilihan sampel menggunakan teknik simple random sampling yang dilakukan secara acak. Adapun desain dalam penelitian ini adalah sebagai berikut:

Tabel 1. Rancangan Penelitian One Group Pre-test Post-test Design

\begin{tabular}{cccc}
\hline Kelas & $\begin{array}{c}\text { Pre- } \\
\text { test }\end{array}$ & $\begin{array}{c}\text { Perlaku } \\
\text { an }\end{array}$ & $\begin{array}{c}\text { Post- } \\
\text { test }\end{array}$ \\
\hline X IPA 1 & $\mathrm{O}_{1}$ & $\mathrm{X}$ & $\mathrm{O}_{2}$ \\
X IPA 2 & $\mathrm{O}_{1}$ & $\mathrm{X}$ & $\mathrm{O}_{2}$ \\
X IPA 3 & $\mathrm{O}_{1}$ & $\mathrm{X}$ & $\mathrm{O}_{2}$ \\
\hline
\end{tabular}

Keterangan:

$\mathrm{X}$ : penerapan model pembelajaran ECIRR

$\mathrm{O}_{1} \quad$ : sebelum penerapan pembelajaran ECIRR

$\mathrm{O}_{2}$ : sesudah penerapan pembelajaran ECIRR

Pada penelitian ini teknik pengumpulan data adalah berdasarkan lembar pengamatan keterlaksanaan model pembelajaran ECIRR dan perbedaan hasil pre-test post-test peserta didik. Pre-test diberikan kepada peserta didik sebelum proses pembelajaran menggunakan model ECIRR dan post-test dilaksanakan setelah proses pembelajaran menggunakan model ECIRR dilaksanakan. Pengolahan data hasil pre-test dan post-test peserta didik diawali dengan pemberian skor dan kemudian menghitung rata-rata untuk mengetahui perbedaan hasil belajar peserta didik sebelum dan sesudah melakukan pembelajaran menggunakan model ECIRR. Data hasil belajar selanjutnya dianalisis meggunakan uji normalitas, uji U-Man Whitney, uji homogenitas, dan analisis n-gain.

\section{HASIL DAN PEMBAHASAN}

Penelitian ini dilaksanakan di SMA Negeri 1 Ponggok dan pengamatan dilakukan oleh guru mata pelajaran fisika. Kegiatan pengamatan tersebut barkaitan dengan keterlaksanaan tahap-tahap pada proses pembelajaran menggunakan model ECIRR. Berikut adalah hasil analisis keterlaksanaan pembelajaran dengan menggunakan model ECIRR yang diamati oleh guru Fisika SMA Negeri 1 Ponggok.

Tabel 2. Rekapitulasi Hasil Analisis

Keterlaksanaan Model Pembelajaran ECIRR

\begin{tabular}{ccccc}
\hline \multirow{2}{*}{$\mathrm{N}$} & Aspek yang & \multicolumn{3}{c}{ Kelas } \\
\cline { 3 - 5 } $\mathrm{O}$ & diamati & XA & XA & XA \\
& & 1 & 2 & 3 \\
\hline
\end{tabular}

Tahap 1. Elicit

Menyajikan situasi

atau sebuah

1 fenomena untuk $4 \quad 4 \quad 3$ menstimulus

pemikiran peserta didik

\section{Tahap 2. Confront}

Mengajukan

2 pertanyaan terkait $3 \quad 4 \quad 4 \quad 4$ situasi atau

femomena tersebut

Tahap 3. Identify

Membeturkan


ditawarkan oleh peserta didik

Tahap 4. Resolve

Memfasilitasi

peserta didik untuk

4 melakukan

kegiatan guna

membuktikan

suatu konsep

Tahap 5.

Reinforce

5 Menstimulus

peserta didik untuk

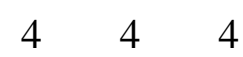

mencari

keisimpulan

6 Penutup

Memberikan

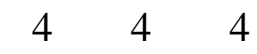

4 


\begin{tabular}{clll}
\hline $\begin{array}{l}\text { penguatan terkait } \\
\text { konsep yang tepat }\end{array}$ & & & \\
\hline Jumlah & 21 & 22 & 22 \\
\hline
\end{tabular}

Berdasarkan hasil pengamatan pada Tabel 2 bahwa pada kegiatan pendahuluan yang meliputi kegiatan pendahuluan yaitu melakukan apersepsi dengan mengkaitkan materi dengan pembelajaran yang telah dilakukan dan melakukan kegiatan untuk memotivasi peserta didik kemudian menyampaikan tujuan pembelajaran. Tahap pertama (Elicit) guru menyajikan fenomena Gerak Lurus yang ada dalam kehidupan sehari-hari untuk menstimulus pemikiran peserta didik. Tahap kedua (Confront) guru mengajukan pertanyaan terkait fenomena Gerak Lurus yang ada dalam kehidupan sehari-hari. Tahap ketiga (Identify) guru menanyakan alasan atas keyakinan atau ketidakyakinan dari jawaban yang dipaparkan oleh peserta didik. Tahap keempat (Resolve) guru memberikan fasilitas kepada peserta didik untuk melakukan kegiatan (berupa praktikum) untuk membuktikan konsep pemikiran awal peserta didik. Tahap kelima (Reinforce) guru memberikan stimulus kepada peserta didik untuk mencari kesimpulan. Persentase dari hasil penilaian keterlaksanaan pembelajaran kelas X IPA 1, X IPA 2 dan X IPA 3 adalah pada rentang $81 \%-100 \%$. Keterlaksanaan kegiatan pembelajaran pada kelas X IPA 1 adalah sebesar 87,50\% dan pada kelas X IPA 2 dan X IPA 3 adalah sebesar $91,67 \%$ yang dikategorikan sangat baik. Dari hasil persentase keterlaksanaan proses pembelajaran ini, maka pembelajaran model ECIRR dapat dikatakan berhasil karena sudah lebih dari rentang 41\%-60\% atau keterangan kriteria cukup.

Dari hasil data Pre-test dan Post-test dilakukan uji normalitas. Pada penelitian ini uji normalitas dilakukan setelah peserta didik mengerjakan soal pre-test dan posttest dan dilakukan menggunakan uji one sample Kolmogorov-smirnov dengan taraf sig. 0,05. Dasar pengambilan keputusan dalam uji normalitas adalah sebagai berikut: jika signifikan $p$-value $<\alpha=0,05$ maka data berdistribusi tidak normal dan jika signifikan $p$-value $>\alpha=0,05$ maka data berdistribusi normal. Adapun hasil uji normalitas pada penelitian ini adalah sebagai berikut:

Tabel 3. Hasil Uji Normalitas

\begin{tabular}{llccc}
\multicolumn{4}{l}{ Kolmogorov-Smirnov $^{\mathrm{a}}$} \\
\hline Kelas & Statistic & Df & Sig. \\
\hline Hasil & Pre-test A1 & .188 & 27 & .015 \\
Belajar & Post-test & .130 & 27 & $.200^{*}$ \\
& A1 & & & \\
& Pre-test A2 & .123 & 27 & $.200^{*}$ \\
& Post-test & .143 & 27 & .162 \\
& A2 & & & \\
& Pre-test A3 & .170 & 27 & .044 \\
& Post-test & .191 & 27 & .013 \\
& A3 & & & \\
\hline
\end{tabular}

Berdasarkan hasil perhitungan uji normalitas menunjukkan bahwa nilai signifikan pada pre-test kelas X IPA 1 adalah 0,015 berarti bahwa data berdistribusi tidak normal dan pada data post-test adalah sebesar 0,200 berarti bahwa data berdistribusi normal. Pada kelas X IPA 2 untuk data pre-test nilai signifikan sebesar 0,200 menunjukkan bahwa data berdistribusi normal dan pada post-test niai signifikan adalah 0,162 maka data tersebut berdistribusi normal. Pada kelas X IPA 3 nilai signifikan pada pre-test dan post-test adalah 0,044 dan 0,013 menunjukkan data berdistribusi tidak normal.

Berdasarkan uji normalitas menggunakan uji Kolmogorov-Smirnov didapatkan hasil bahwa data nilai pre-test pada kelas X IPA 1 dan pre-test post-test kelas X IPA 3 berdistribusi tidak normal. Untuk mengetahui apakah terdapat perbedaan hasil belajar peserta didik menggunakan statistik non parametrik, yaitu menggunakan uji $U$ Man Whitney. Dasar pengambilan keputusan pada uji U-Man Whitney adalah hipotesis diterima jika nilai Asymp.Sig < 0,05 dan hipotesis ditolak jika nilai Asymp.Sig $>0,05$. Berikut adalah data hasil 
uji U-Man Whitney untuk kelas X IPA 1, X IPA 2, dan X IPA 3.

Tabel 4. Hasil Perhitungan Uji U-Man Whitney

\begin{tabular}{cccc}
\hline No & Kelas & $\begin{array}{c}\text { Jumlah } \\
\text { Sampel }\end{array}$ & $\begin{array}{c}\text { Asymp. Sig. } \\
\text { (2-tailed) }\end{array}$ \\
\hline 1 & X IPA 1 & 27 & 0,000 \\
2 & X IPA 2 & 27 & 0,001 \\
3 & X IPA 3 & 27 & 0,002 \\
\hline
\end{tabular}

Berdasarkan data pada Tabel 5 diketahui bahwa nilai Asymp. Sig (2-tailed) pada kelas X IPA 1 sebesar 0,000 $<0,05$ pada kelas X IPA 2 sebesar 0,001 $<0,05$ dan pada kelas X IPA 3 sebesar 0,002 < 0,05 . Maka dapat disimpulkan bahwa hipotesis diterima. Dengan demikian dapat dikatakan bahwa ada perbedaan yang signifikan pada hasil belajar peserta didik pada materi Gerak Lurus yang menggunakan model ECIRR

Uji selanjutnya yang dilakukan adalah uji homogenitas. Uji homogenitas pada penelitian ini dilakukan setelah peneliti mendapatkan data hasil pre-test dan posttest. Kriteria dalam pengambilan keputusan pada uji homogenitas adalah jika nilai sig. > 0,05 maka $\mathrm{H}_{0}$ diterima dan sebaliknya jika sig. $<0,05$ maka $\mathrm{H}_{0}$ ditolak. Berikut adalah hasil uji homogenitas menggunakan one way anova menggunakan bantuan program SPSS (Statistical Package for Social Science).

Tabel 5. Hasil Uji Homogenitas Pre-test dan Post-test Menggunakan One Way

Anova

\begin{tabular}{c|c|c|c}
$\begin{array}{c}\text { Test of } \\
\text { Variances }\end{array}$ & \multicolumn{3}{c}{ Homogeneity of } \\
\hline $\begin{array}{c}\text { Levene } \\
\text { Statistic }\end{array}$ & df1 & df2 & Sig. \\
\hline 1.330 & 2 & 78 & .270 \\
\hline
\end{tabular}

erdasarkan data hasil uji homogenitas one way anova dapat diketahui nilai sig. adalah sebesar 0,270. Dari hasil hitung ini menunjukkan nilai sig. $>0,05$ atau 0,27 > 0,05 sehingga dapat disimpulkan bahwa $\mathrm{H}_{\mathrm{o}}$ diterima dan berarti varian data termasuk dalam kategori homogen.

Pada penelitian ini hasil belajar peserta didik didapat berdasarkan hasil tes pre-test dan post-test. Hasil pre-test dan post-test digunakan untuk mengetahui tingkat penguasaan materi peserta didik pada materi pembelajaran Gerak Lurus Berikut ini adalah rata-rata nilai pre-test dan post-test pembelajaran materi Gerak Lurus dengan model ECIRR.



Gambar 1. Grafik Perbandingan Rata-Rata Nilai Pre-Test Dan Post-Test

Dari gambar 1 dapat diketahui bahwa hasil post-test mengalami peningkatan setelah diberikan perlakuan yaitu pembelajaran menggunakan model ECIRR. Pada saat proses pembelajaran berlangsung peserta didik terlibat aktif melakukan tanya jawab. Keaktifan peserta didik terlihat pada saat peneliti memberikan penjelasan dan pada saat peneliti memberikan contoh soal. Pada model pembelajaran ECIRR peserta didik dibagi berkelompok untuk berdiskusi memecahkan masalah. Saat diskusi berlangsung, terdapat kelompok yang kesulitan untuk memecahkan masalah. Terdapat kelompok yang tidak bisa mengakses atau membuka aplikasi Phet Collorado. Sehingga peneliti membimbing kelompok yang mengalami kesulitan tersebut agar materi yang diberikan dapat diterima baik oleh peserta didik. Dengan demikian dapat diketahui bahwa penerapan model ECIRR dapat meningkatkan hasil belajar peserta didik khususnya pada materi Gerak Lurus.

Selanjutnya dilakukan analisis n-gain agar dapat mengetahui peningkatan hasil 
belajar peserta didik setelah diberi perlakuan. Berikut adalah tabel hasil perhitungan n-gain.

Tabel 6. Hasil Perhitungan n-gain

\begin{tabular}{ccc}
\hline Kelas & $\langle\mathrm{g}\rangle$ & Kategori \\
\hline X IPA 1 & 0,39 & Sedang \\
X IPA 2 & 0,39 & Sedang \\
X IPA 3 & 0,31 & Sedang \\
\hline
\end{tabular}

Dari hasil perhitungan n-gain dapat di ketahui bahwa peserrta didik mengalami peningkatan hasil belajar dalam kategori sedang.

\section{KESIMPULAN}

Berdasarkan penelitian yang telah dilakukan dapat disimpulkan bahwa berdasarkan rata-rata n-gain penerapan pembelajaran menggunakan model ECIRR berpengaruh terhadap hasil belajar peserta didik dalam kategori sedang pada materi Gerak Lurus kelas X SMA Negeri 1 Ponggok. Keterlaksanaan pembelajaran menggunakan model ECIRR dikategorikan sangat baik. Dengan demikian pembelajaran menggunakan model ECIRR dapat digunakan sebagai salah satu pilihan model pembelajaran untuk meningkatkan hasil belajar peserta didik.

\section{DAFTAR PUSTAKA}

Andriani, N. L. Y., Darsikin, \& Hatibe, A. (2016). Analisis Kesulitan Siswa Dalam Menyelesaikan Soal Gerak Lurus. Jurnal Pendidikan Fisika Tadulako. 4(3), 36-41.

Ardiansyah, Dirgantara, Y., Agustina, R. D., \& Sugilar, H. (2019). Penerapan Model Pembelajaran ECIRR (Elicit, Confront, Identify, Resolve, Reinforce) Untuk Meningkatkan Kemampuan Pemecahan Masalah Peserta Didik Pada Materi Fluida Statis. Jurnal Penelitian Pembelajaran Fisika. 10(1), 77-82.

Artiawati, P. R., Muliyani, R., \& Kurniawan, Y. (2016). Identifikasi Kuantitas Siswa Yang Miskonsepsi Menggunakan Three Tier-Test Pada
Materi Gerak Lurus Beraturan (GLB). Jurnal Ilmu Pendidikan Fisika. 1(1), 13-15.

Dwi Priyanto, Mandiri Belajar SPSS (Untuk Analisis dan Uji Statistik), (Yogyakarta : Mediakom, 2008).

Fathurrahman, Muhammad. (2015). ModelModel Pembelajaran Iovatif. Yogyakarta: Ar-Ruzz Media.

Kurniawati, L., Masruro, U., \& Afidah. (2020). Pengaruh Strategi Pembelajaran ECIRR Terhadap Kemampuan Berpikir Kritis Matematis Siswa. Algoritma Journal of Mathematics Education. 2(1), 8699.

Ma'rifa, Kamaluddin, H., \& Fihrin, $\mathrm{H}$. (2018). Analisis Pemahaman Konsep Gerak Lurus Pada Siswa SMA Negeri di Kota Palu. Jurnal Pendidikan Fisika Tadulako. 4(3), 13.

Mahardini, M. M. A. (2020). Analisis Situasi Penggunaan Google Classroom Pada Pembelajaran Daring Fisika. Jurnal Pendidikan Fisika. 8(2), 215-224.

Maulida, E. A., \& Suliyanah. (2016). Profil Miskonsepsi Siswa Dalam Model ECIRR Berbantuan PhET Simulation Pada Materi Momentum, Impuls, dan Tumbukan. Jurnal Inovasi Pendidikan Fisika. 5(3), 202-205.

Mustofa, M. H., \& Rusdiana, D. (2016). Profil Kemampuan Pemecahan Masalah Siswa Pada Pembelajaran Gerak Lurus. Jurnal Penelitian \& Pengembangan Pendidikan Fisika. 2(2), 15-22.

Napsawati. (2020). Analisis Situasi Pembelajaran IPA Fisika Dengan Metode Daring Di Tengan Wabah Covid-19. Jurnal Pendidikan Fisika dan Terapannya. 3(1), 6-12.

Pahrudin, A., et al. (2020). The Effects of the ECIRR Learning Model on Mathematical Reasoning Ability in the Curriculum Perspective 2013: Integration of Student Learning 
Motivation. European Journal of Educational Research. 9(2), 675684.

Prastiwi, A. C., et al. (2018). Implementation of ECIRR Model Based on Virtual Simulation Media to Reduce Students Misconception on Kinetic Theory of Gases. Journal of Physics.

Pujianto, A., Nurjannah, \& Darmadi, I., W. (2013). Analisis Konsepsi Siswa Pada Konsep Kinematika Gerak Lurus. Jurnal Pendidikan Fisika Tadulako. 1(1), 16-21.

Setyono, A., Nugroho, S. E., \& Yulianti, I. (2016). Analisis Kesulitan Siswa Dalam Memecahkan Masalah Fisika Berbentuk Grafik. Unnes Physics Education Journal. 5(3), 32-39.
Suhendi, H. Y., Kaniawati, I., \& Maknun, J. 2014. Peningkatan Pemahaman Konsep dan Profil Miskonsepsi Siswa Berdasarkan Hasil Diagnosis Menggunakan Pembelajaran ECIRR Berbantuan Simulasi Virtual dengan Instrument Three-Tier Test. Mathematics and Sciences Forum.

Sugiyono. Metode Penilitian Pendidikan, Pendekatan Kuantitatif, Kualitatif, dan R\&D. Bandung: Alfabeta;2014.

Wulandari, C. A., \& Rusmini. (2020). Validitas Teoritis LKPD Untuk Mereduksi Miskonsepsi Pada Materi Stoikiometri Menggunakan Model Pembelajaran ECIRR Untuk Kelas $\mathrm{X}$ SMA. UNESA Journal of Chemical Education. 9(2), 265-274. 